[6] Kiptelaya, L., Zahorulko, A., Zagorulko, A., Liashenko, B. (2017). Improvement of IR emitter to create non-reflector dryer for plant raw materials. Technology Audit and Production Reserves, 2 (3 (34)), 17-22. doi: https://doi.org/10.15587/23128372.2017.98068

[7] Chto takoe pasterizatsiya. Available at: http://vpmash.ru/articles/chto-takoe-pasterizatsiya.html

[8] Vyshnevskyi, I. M., Sakhno, V. I., Tomchay, S. P., Zelinskyi, A. G., Sakhno, O. V. (2005). Implementation of the Technologies for Radiation Pasteurization and Preservation of Food Products. Nauka Ta Innovacii, 1 (3), 51-61. doi: https://oi.org/10.15407/ $\operatorname{scin} 1.03 .051$

[9] Mavrin, E. A. (2015). Parametric synthesis of the annular thin-layer apparatus for pasteurization of milk. Vestnik Orenburgskogo gosudarstvennogo universiteta, 9 (184), 158-163.

[10] Dilay, E., Vargas, J. V. C., Amico, S. C., Ordonez, J. C. (2006). Modeling, simulation and optimization of a beer pasteurization tunnel. Journal of Food Engineering, 77 (3), 500-513. doi: https://doi.org/10.1016/j.jfoodeng.2005.07.001

[11] Taner Elmas, E. (2020). Design and production of high temperature heat pipe heat recovery units. Journal of Molecular Structure, 1212, 127927. doi: https://doi.org/10.1016/j.molstruc.2020.127927

[12] DSTU 3662-97. Moloko koroviache nezbyrane. Available at: https://dnaop.com/html/34011/doc-\%D0\%94\%D0\%A1\%D0\% A2\%D0\%A3_3662-97

[13] DSTU 2661:2010. Drinking cow milk. General technical specifications. Available at: http://ukrapk.com/gosts/milk/dsty_ 26612010_moloko_korovyache_pitne.html

\title{
PROSPECTS OF USING SPINACH IN PRODUCTION TECHNOLOGY OF CHAPATTI OF WHOLEGRAIN FLOUR
}

\author{
Tatiana Belemets \\ Department of Biotechnology and Microbiology ${ }^{1}$ \\ Tatiana_Belemets@i.ua \\ Irina Radzievskaya \\ Department of Technology of fats and perfumery-cosmetic products ${ }^{1}$ \\ logos2007@ukr.net \\ Nataliia Yushchenko \\ Department of Restaurant Technology and Ayurvedic Products ${ }^{1}$ \\ YuNM_NUFT@ukr.net \\ Uliana Kuzmyk \\ Department of Milk and Dairy Product Technology \\ ukuzmik@gmail.com \\ ${ }^{1}$ National University of Food Technologies \\ 68 Volodymyrska str., Kyiv, Ukraine, 01601
}

\section{Abstract}

It is urgent to enrich floury products with vegetable magnesium sources. One of such plants is garden spinach - one-year plant, a representative of Spinacia genus. For this aim, there were studied functional-technological properties of wholegrain flour for substantiating preparation in the chapatti technology.

Research results demonstrated that barley flour had the most water-absorbing capacity $-400 \%$, this parameter was almost twice less in rice and wheat flour. The most fat-retaining capacity was inherent to barley flour $-87 \%$, whereas in the control (highest sort wheat flour) this index was $25 \%$. 
Technological parameters of spinach preparation in the chapatti composition have been determined: particles size - 250 up to mcm; optimal amount of introduction of wholegrain flour to the mass $-3 \%$; swelling process duration after dough mixing $-15-20$ min for creating a total spatial structure.

The energetic value calculation testifies that the caloric number of chapatti is unessential, comparing with main dishes and is in average $220.0 \mathrm{kcal} / 100 \mathrm{~g}$.

Thus, the use of spinach together with wholegrain flour in chapatti gives a possibility to increase a provision degree of the daily need in main nutritive substances for the human organism.

The aim of the work is to develop technologies of new types of culinary products and their introduction at public food enterprises.

Keywords: spinach, wholegrain flour, food value, chapatti, organoleptics, water-absorbing capacity, fat-retaining capacity, disperse composition, acidity.

DOI: $10.21303 / 2504-5695.2020 .001381$

\section{Introduction}

Balanced nutrition is a guarantee and necessary condition of the normal development and formation of the human organism. Floury products as ones of mass consumption are most available for correcting food and biological values of the human ration [1, 2]. They are usually produced of highest sort flour, so they have rather high energetic value, because flour by $70 \%$ consists of easily assimilated carbohydrates [3]. The energetic value of flour is mainly conditioned by the presence of starch. Depending on type and sort, it is $290-330 \mathrm{kcal} / 100 \mathrm{~g}$ [4]. Protein substances are $6.5 \ldots 11 \%$. They are represented by proteins and also products of their hydrolysis - peptides, polypeptides, amides and amino acids. Flour contains from 9 to $15 \%$ of bound water. At such moisture content flour has a long storage term $[5,6]$.

Floury products of whole grains are highly demanded by modern consumers, because they include all useful substances of a grain, lost at sort grinding. Flour, produced of different types of grain, differs by different contents of chemical substances, color, use. Main types of flour are wheat and rye. Oat, rice and buckwheat flour is used for child and dietetic nutrition, for confectionary and food-concentrate branches - corn, soya, pea and so on [7].

The use of wholegrain flour in floury products technology has a series of limitations, connected with visible inclusions of a comminuted tunic and specific organoleptic properties. Alongside with it, wholegrain flour contains all high-value grain components, often absent in sort flour.

Chapatti is a traditional yeast-free product of the Indian kitchen, based on unleavened dough, similar to pancakes by form [8]. Its technology may be adapted to the use of wholegrain flour, and the use of natural enriching components allows to raise the food value of products and to give them functional properties.

One of urgent problems of the modern world is microelement deficiency, first of all connected with increased consumption volumes of refined products. It may be a cause of functioning disturbance of biochemical processes in the human organism and one of diseases. One of such problems is magnesium deficiency that conditions worsening of the general health condition, chronic fatigue syndrome.

That is why it is urgent to enrich floury products with vegetable sources of magnesium. One of these plants is garden spinach - one-year plant, representative of Spinacia genus, popular throughout the world.

Spinach is remarkable for high food value and contains an essential amount of organically bound easily assimilated ferrum and other elements - potassium, phosphorus, magnesium. In also contains vitamins $\mathrm{C}, \mathrm{B}_{1}, \mathrm{~B}_{2}, \mathrm{~B}_{6}, \mathrm{PP}, \mathrm{E}$ and $\mathrm{K}$. The anti-rachitic vitamin $\mathrm{D}_{2}$ and also chlorophyll, which content is familiar to blood hemoglobin, condition the spinach importance for child and dietetic nutrition [9]. Unfortunately, organoleptic parameters of spinach may limit its use, so the improvement of the technology of everyday food products by using spinach or its processing products is an urgent problem of scientific studies.

The aim of the work is to develop technologies of new types of culinary products and their introduction at public food enterprises. 


\section{Materials and Methods}

Wholegrain rice, barley and wheat flour, dry comminuted spinach (originated from Ukraine) were used for producing chapatti.

The water-absorbing capacity of wholegrain flour was determined by volume of the swelled product [10]. A product batch with mass $5 \mathrm{~g}$ was weighted in a glass, mixed with $10 \mathrm{ml}$ of distilled water and the total volume was added to $100 \mathrm{~cm}^{3}$, accurately mixed and left for 4 hours. Then the swelled product volume was measured beyond a separation limit between a hydrated residue and above-residual liquid.

The ability to swelling $H$ was determined by the formula:

$$
H=(V / m) * 100 \%
$$

where $V$ - swelled product volume, $\mathrm{cm}^{3} ; m$ - product batch mass, $\mathrm{g}$.

The water-retaining capacity was determined by the centrifuging method. At that samples of $4 \mathrm{~g}$ were placed in centrifuge test tubes and centrifuged at $1500 \mathrm{turn} / \mathrm{min}$.

The studies of the fat-retaining capacity were conducted as follows: a batch of $4 \mathrm{~g}$ was placed in a centrifuge test tube and sunflower oil was added to $10 \mathrm{ml}$ mark [10]. The test tube was kept in a thermostat at $20^{\circ} \mathrm{C}$, periodically mixing suspension during $30 \mathrm{~min}$. After that, centrifuged at $15000 \mathrm{turn} / \mathrm{min}$ during $15 \mathrm{~min}$. The above-residual liquid (supernant) was measured. The fat-retaining capacity (FRC) in $\mathrm{ml} / \mathrm{g}$ was calculated by the formula:

$$
F R C=(10-a) / 4
$$

where 10 - amount of introduced oil; $a$ - volume of supernant; 4 - sample batch, $\mathrm{g}$.

The active acidity was determined potentiometrically on the universal ionometer EV-74.

The food value was determined by calculating a correspondence percent of the integral score of each most important component to the daily need.

Chapatti samples were produced by the following technological scheme: raw materials approval by quality and quantity; their preparation to production; dough mixing dough shaking; frying; ready product; portioning [8]. Wholegrain flour and kitchen salt were inspected, sieved through a sieve for eliminating side admixtures. The prepared recipe components were mixed, water was added, and shaken during $5 \mathrm{~min}$ to the homogenous mass, gradually adding the rest water. If clots formed in the dough, it was filtered. The poured dough was distributed equally by frying pan rotation and fried. Chapatti was baked on hot oiled frying pans at temperature $(120-130)^{\circ} \mathrm{C}$ during 2-5 min. Ready chapatti was portioned.

\section{Results}

In industry the important characteristic of flour is water- and fat-retaining capacity, because it conditions an amount of water, necessary for dough mixing. This characteristic is conditioned by chemical and physical properties of protein, and depends on its disperse composition.

For substantiating preparation of wholegrain flour in the chapatti production technology, its functional-technological properties were studied.

The studies of grinding sizes of wholegrain flour were conducted using a set of sieves with different orifice sizes, the results are presented in Fig. 1.

The analysis of the disperse composition demonstrates that particles with size $144 \mathrm{mcm}$ in rice, barley and wheat flour are $94 \%, 80 \%$ and $96 \%$ respectively. Comparing the content of fractions with size $144 \mathrm{mcm}$, one can make a conclusion that rice and wheat flour are characterized by the most dispersion.

Taking into account the dispersion composition of wholegrain flour, its water-absorbing and water-retaining capacity was determined. The research results demonstrated (Fig. 2) that barley flour had most water-absorbing capacity $400 \%$, this index was twice less for rice and wheat flour.

For comparing, wheat flour of the highest sort was chosen as a control. The results demonstrated that the water-absorbing capacity of the control and for rice flour was $220 \%$. 


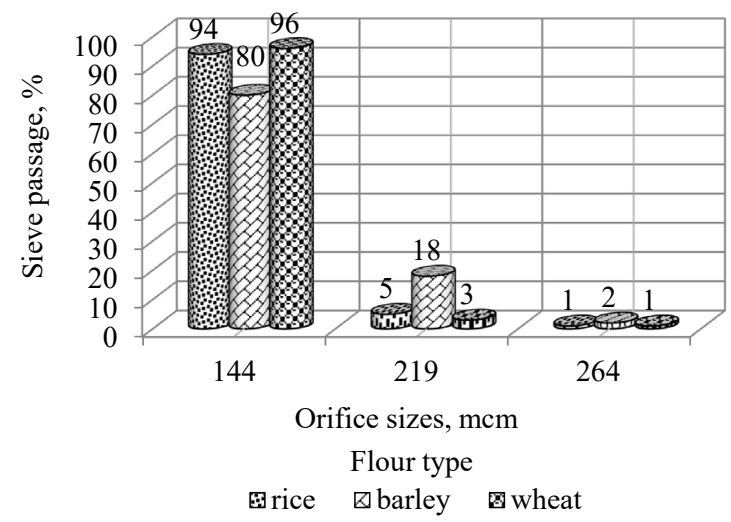

Fig. 1. Disperse composition of different types of wholegrain flour

Such result may be explained by the fact that barley flour is characterized by the highest content of cellulose and its better availability for hydration at mechanical comminution and also by the difference of morphological signs of cultures, influencing protein properties.

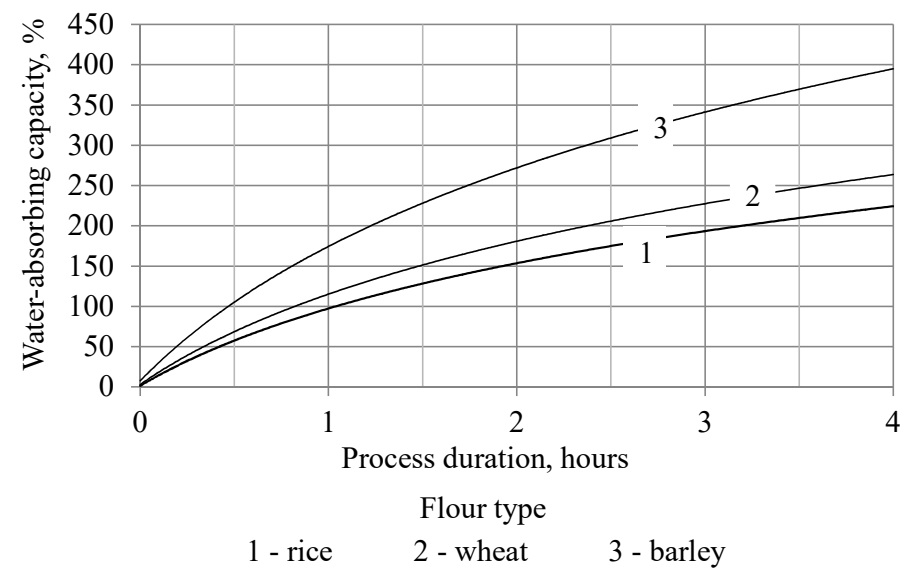

Fig. 2. Water-absorbing capacity of wholegrain flour

But the water-retaining capacity was equal for all types of wholegrain flour and for the control as $1 \%$, the data are presented in Fig. 3.

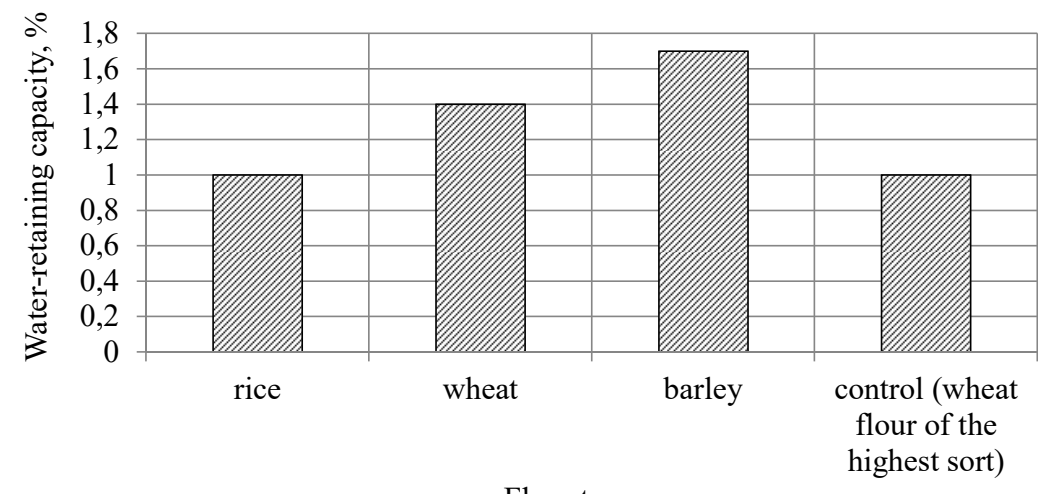

Fig. 3. Water-retaining capacity of different types of wholegrain flour and one of the highest sort

Analyzing the obtained results of determining the fat-retaining capacity, we can see (Fig. 4) that the highest index is in barley flour that is $87 \%$. This index of wheat and rice flour is $82 \%$ and $62 \%$ respectively. 


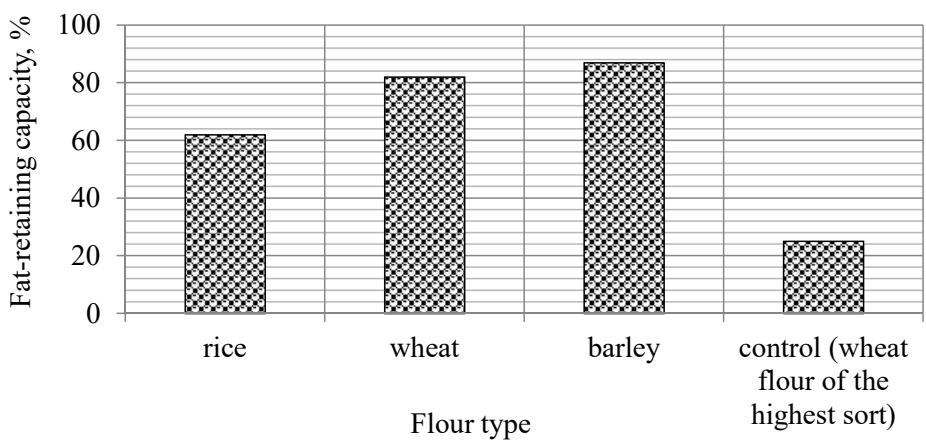

Fig. 4. Fat-retaining capacity of different types of wholegrain flour and one of the highest sort

Such results may be explained by the fact that barley contains more water-soluble proteins that mainly play an emulsifying role.

It has been established by the experimental way, that the acidity of chosen flour types is within 5.2-6.2 pH (Fig. 5).

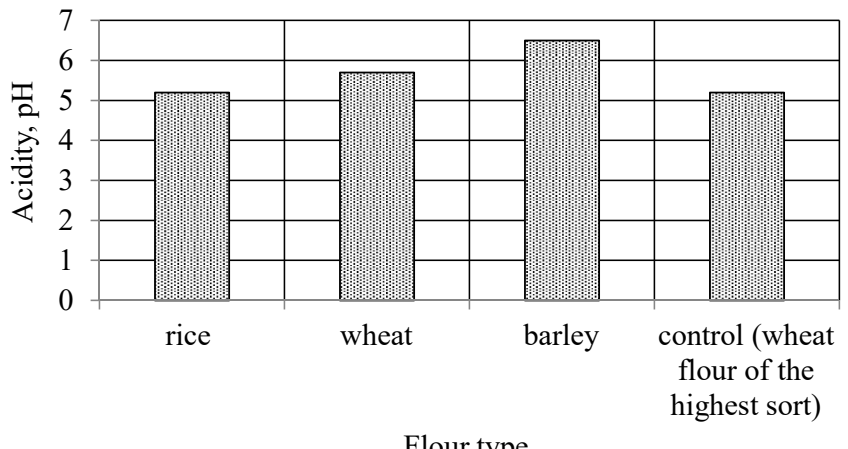

Fig. 5. Acidity of different types of wholegrain flour and one of the highest sort

Thus, the research results allow to recommend wholegrain flour as a raw material with certain technological properties that must be taken into account at forming structural-mechanical properties of chapatti.

A promising method for processing raw materials is making power-like additives by drying vegetable raw materials that allows to get high-quality products. Drying is the most rational preserving way, because microbiological processes in dried products decelerate, and the content of biologically active substances remains close to natural $[11,12]$. That is why it is offered to use spinach as dry powder in the chapatti technology.

The quality of food products is influenced by the disperse composition of vegetable raw materials, because particles with sizes more than $400 \mathrm{mcm}$ may cause defects of organoleptic assessment. Taking it into account, the dispersed composition of spinach was studied (Fig. 6).

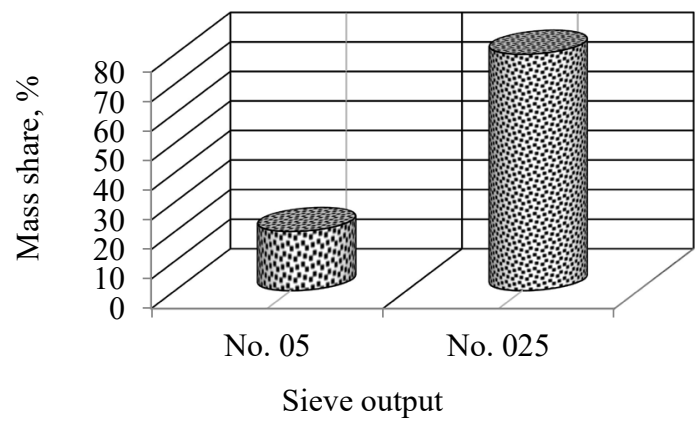

Fig. 6. Distribution of dry spinach particles sizes 
Based on the data of Fig. 6, the disprsed composition of spinach is mainly particles of $250 \mathrm{mcm}$.

As far as water-absorbing capacity was an important technological characteristic, this index of spinach powder was studied. Distilled water was chosen for studying this characteristic as a solvent. The depencence of the water-absorbing capacity on the process duration is presented on Fig. 7.

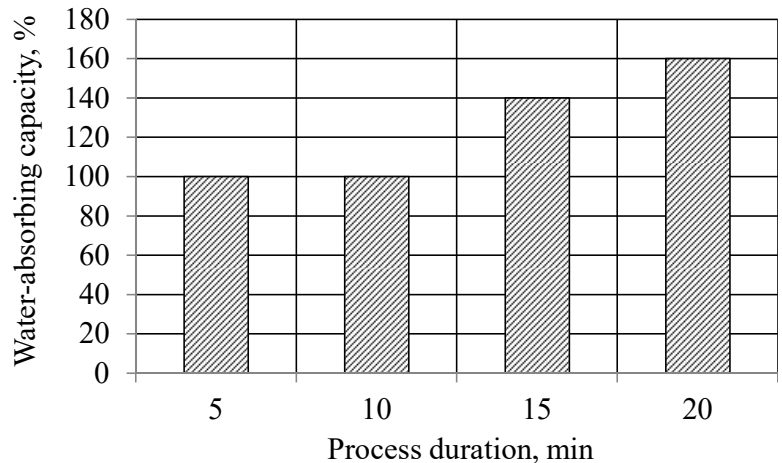

Fig. 7. Water-absorbing capacity of dry spinach

The analysis of the data testifies that the powder intensive swelling process takes place during $20 \mathrm{~min}$. That is why it is necessary to leave dough for 15-20 min after mixing spinach with other recipe components for forming a total spatial structure.

The mass share and dispersion of food additives, interaction between their components and with side ones play an important role in the formation of organoleptic properties of a ready product.

The influence of spinach introduction amount on the organoleptic assessment of chapatti was studied (Fig. 8).

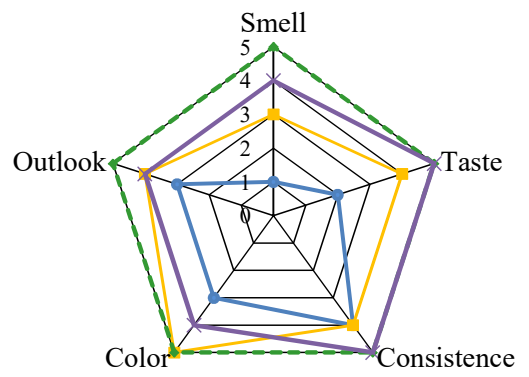

Spinach introduction amount, $\%$ :

$\rightarrow 1 \rightarrow-2 \rightarrow-3 \leftrightarrow 4$

Fig. 8. Profilogram of the organoleptic assessment of model samples of chapatti with spinach

The obtained data demonstrate that $3 \%$ may be selected as a rational amount of spinach addition to the dish that allows to provide the high organoleptic mark of chapatti.

The acidity of new products didn’t change at storage and remained at level 5.2-6.2 pH (Fig. 9).

According to the conducted studies and made conclusions, recipes and technological instructions for the products have been developed.

The calculation of the chemical composition and food value of new chapatti according to the content of main food substances are presented in Table 1 [13].

The calculation of the energetic value testifies to the fact that the caloric number in chapatti is unessential, comparing with main dishes and is $220.0 \mathrm{kcal} / 100 \mathrm{~g}$.

Thus, the use of spinach together with wholegrain flour in the chapatti composition gives a possibility to increase satisfaction of the human organism's daily need in main nutritive substances. 


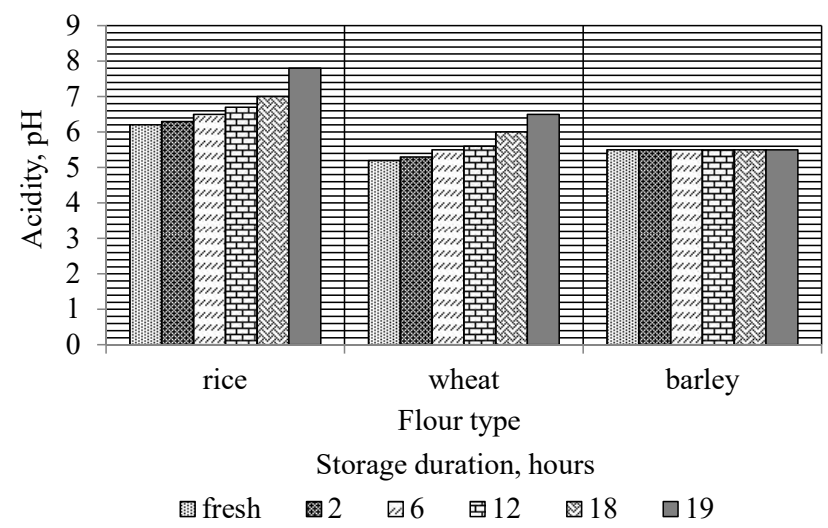

Fig. 9. Active acidity of chapatti at storage

Table 1

Chemical composition and energetic value of chapatti

\begin{tabular}{|c|c|c|c|}
\hline \multirow{3}{*}{ Food substances } & \multicolumn{3}{|c|}{ Content of nutritive substances in $100 \mathrm{~g}$ of the ready product } \\
\hline & \multicolumn{3}{|c|}{ Flour type } \\
\hline & Rice & Wheat & Barley \\
\hline proteins & 6.1 & 8.4 & 6.0 \\
\hline Fats & - & - & - \\
\hline Carbohydrates & 51.0 & 49.5 & 42.0 \\
\hline \multicolumn{4}{|c|}{ Mineral substances, $\mathrm{mg}$} \\
\hline sodium & 15.0 & 9.0 & 36.0 \\
\hline potassium & 144.0 & 120.0 & 285.0 \\
\hline calcium & 15.0 & 27.0 & 126.0 \\
\hline magnesium & 43.5 & 25.5 & 75.0 \\
\hline phosphorus & 120.0 & 57.0 & 213.0 \\
\hline ferrum & 0.6 & 0.6 & 1.5 \\
\hline \multicolumn{4}{|c|}{ Vitamins, mg } \\
\hline C (ascorbic acid) & 6.0 & 6.0 & 6.0 \\
\hline B1(thiamin) & 0.06 & 0.1 & 0.3 \\
\hline Energetic value, $\mathrm{kcal} / 100 \mathrm{~g}$ & 229.2 & 231.6 & 192.0 \\
\hline
\end{tabular}

\section{Conclusions}

The technological properties of wholegrain flour: faction composition, water-absorbing, water-retaining and fat-retaining capacities have been studied.

It has been established, that wholegrain flour has the water-retaining capacity index at almost the same level, comparing with the control, wheat flour. The research results demonstrated that barley flour had the most water-absorbing capacity $-400 \%$, this parameter was almost twice less in rice and wheat flour. The most fat-retaining capacity was inherent to barley flour $-87 \%$, whereas in the control this index was $25 \%$.

The technological parameters of spinach preparation in the chapatti composition have been determined: particles size - up to $250 \mathrm{mcm}$; optimal amount of introduction of wholegrain flour to the mass $-3 \%$; swelling process duration after dough mixing - 15-20 min for creating a total spatial structure.

The energetic value calculation testifies that the caloric number of chapatti is unessential, comparing with main dishes and is in average $220.0 \mathrm{kcal} / 100 \mathrm{~g}$. The protein content in the studied samples is $6-8.4 \mathrm{~g}$, carbohydrates $-42-51 \mathrm{~g}$ in $100 \mathrm{~g}$. Chapatti contains such important mineral 
elements as calcium, phosphorus, magnesium, potassium, ferrum. Spinach addition allows to raise the content of ascorbic acid up to $6 \mathrm{mg}$ in $100 \mathrm{~g}$.

The obtained data may be used for developing technological culinary production schemes at public food enterprises. Creation and introduction of such products to mass consumption allow to widen the assortment of functional products and to improve the population health.

\section{References}

[1] González-Montemayor, Á.-M., Flores-Gallegos, A. C., Contreras-Esquivel, J.-C., Solanilla-Duque, J.-F., Rodríguez-Herrera, R. (2019). Prosopis spp. functional activities and its applications in bakery products. Trends in Food Science \& Technology, 94, 12-19. doi: https://doi.org/10.1016/j.tifs.2019.09.023

[2] Ferawati, F., Hefni, M., Witthöft, C. (2019). Flours from Swedish pulses: Effects of treatment on functional properties and nutrient content. Food Science \& Nutrition, 7 (12), 4116-4126. doi: https://doi.org/10.1002/fsn3.1280

[3] Pasichnyi, V., Yushchenko, N., Mykoliv, I., Kuzmyk, U. (2015). Structure Stabilization of Fermented-Milk Pastes. Ukrainian Food Journal, 4 (3), 431-439.

[4] Gao, J., Guo, X., Brennan, M. A., Mason, S. L., Zeng, X.-A., Brennan, C. S. (2019). The Potential of Modulating the Reducing Sugar Released (and the Potential Glycemic Response) of Muffins Using a Combination of a Stevia Sweetener and Cocoa Powder. Foods, 8 (12), 644. doi: https://doi.org/10.3390/foods8120644

[5] Ukrainets, A., Kochubei-Lytvynenko, O., Bilyk, O., Zakharevych, V., \& Vasylchenko, T. (2016). A study of the effect of enriched whey powder on the quality of a special-purpose bread. Eastern-European Journal of Enterprise Technologies, 2 (11 (80)), 32-41. doi: https://doi.org/10.15587/1729-4061.2016.65778

[6] Peris, M., Rubio-Arraez, S., Castelló, M. L., Ortolá, M. D. (2019). From the Laboratory to the Kitchen: New Alternatives to Healthier Bakery Products. Foods, 8 (12), 660. doi: https://doi.org/10.3390/foods 8120660

[7] Valente, M. da C. da C., Nascimento, R. A., Santana, E. B., Ribeiro, N. F. da P., Costa, C. M. L., Faria, L. J. G. (2019). Spray drying of extract from Euterpe oleracea Mart.: Optimization of process and characterization of the açaí powder. Journal of Food Process Engineering, 42 (8). doi: https://doi.org/10.1111/jfpe.13253

[8] Kaur, P., Singh, N., Pal, P., Kaur, A. (2018). Traditional and improved paddy varieties: Composition, protein, pasting, and gluten-free chapati making properties. Cereal Chemistry, 95 (5), 666-678. doi: https://doi.org/10.1002/cche.10080

[9] Qin, J., Shi, A., Mou, B., Grusak, M. A., Weng, Y., Ravelombola, W. et. al. (2017). Genetic diversity and association mapping of mineral element concentrations in spinach leaves. BMC Genomics, 18 (1). doi: https://doi.org/10.1186/s12864-017-4297-y

[10] Krainiuk, L. M. (Ed.) (2012). Metody kontroliu yakosti kharchovoi produktsiyi. Sumy: Universytetska knyha, 512.

[11] Bychkov, Ya. M., Dmytriuk, T. I. (2014). Sposoby otrymannia sukhykh poroshkiv z roslynnoi syrovyny. Naukovi pratsi ONAKhT, 1 (46), 204-208.

[12] Tarasenko, T., Yevlash, V., Nyemirich, O., Vasheka, O., Gavrish, A., Kravchenko, O. (2015). Theoretical studies drying ways fruits and vegetables. Naukovyi visnyk Lvivskoho natsionalnoho universytetu veterynarnoi medytsyny ta biotekhnolohiy imeni S. Z. Gzhytskoho, 17 (4), 148-158.

[13] Nakaz No. 272 MOZ Ukrainy vid 18.11.1999 r. Pro zatverdzhennia Norm fiziolohichnykh potreb naselennia Ukrainy v osnovnykh kharchovykh rechovynakh ta enerhiyi. Available at: https://zakon.rada.gov.ua/laws/show/z0834-99\#Text 